\title{
Supporting the Professional Identity Development of Nursing Alumni: A Phenomenology Study
}

\author{
Wulan Noviani $^{1 *}$, Elsye Maria Rosa ${ }^{2}$ \\ ${ }^{1}$ Department of Fundamental Nursing and Nursing Management, School of Nursing, Faculty of Medicine and Health Sciences, \\ Universitas Muhammadiyah Yogyakarta, Yogyakarta, Indonesia; ${ }^{2}$ Department of Nursing Management, Master of Nursing, \\ Universitas Muhammadiyah Yogyakarta, Yogyakarta, Indonesia
}

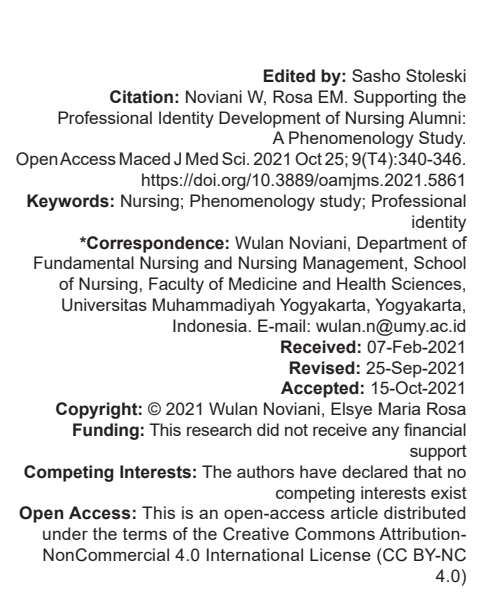

\section{Abstract}

BACKGROUND: Professional identity is the expected outcome of nursing educational institutions reflected in the values, beliefs, attitudes, and behavior of nursing alumni as professional nurses. Nursing alumni's experiences at the Bachelor nursing program in Universitas Muhammadiyah Yogyakarta (UMY) related to professional identity development (PID) at various nursing careers need to be explored.

\begin{abstract}
AIM: This study aims to describe Ners alumni in PID at UMY.
\end{abstract}
METHODS: This study was a phenomenological approach with a maximum variation sampling technique. Seventeen nursing alumni who have been working as professional nurses for a minimum of 2 years and worked in various nursing careers were recruited. A semi-structured interview between 60 and 90 min was conducted. Data analysis used Colaizzi's methods and Nvivo $12^{\mathrm{TM}}$ Plus.

RESULTS: There were two themes emerged from data; (1) Internal motivation to enhancing nursing career, with two sub-themes: having a great personal motivation and developing expertise, (2) External support driving nursing career, with five sub-themes: family encouragement, supports from a leader, accreditation and credential, exemplary role model and positive nursing image.

CONCLUSION: Nursing alumni engaged in a variety of professional roles that contributed to the nursing workforce. The support of PID impacts personal and professional capability and strengthens nurses' careers.

\section{Introduction}

There is a limited consensus regarding the concepts of professional identity in nursing that resulted in an unclear understanding of personal identity in professional occupation [1]. Recently, Fitzergarld (2020) emphasized the concept analysis of professional identity related to attributes, knowledge, values, ethics, personal identity, collective identity, and context of care [2]. In terms of the recognizing of status as a nursing career, professional identity is essential, which can identify the job responsibilities, the role characteristics, and how to carry out the workload [1], [2]. Despite the improvement of nursing professionalism, the stereotypes of nurses' image as a subordinate profession have not changed in several countries globally [3]. Professionalism is a core competency in professional health education and the foundation of practice among professional health workers [4], [5]. There is an urgency to promoting professionalism, especially professional identity development (PID), in the $21^{\text {st }}$ century [6]. Thus, professional identity is essential to status recognition in public, especially nursing [1], [2], [7], [8].
Nursing higher education is an essential element in instilling professional values reflected in the professional identity of its graduates [9] as a character for the nursing profession [10]. Professional identity is defined as a self-concept that represents how nurses or nursing students perceive the nursing profession [11], based on attributes, characters, beliefs, values, and experiences in carrying out professional roles [6], [12] to achieve a sense of identity in a job [13]. Professional identity is a transition from theoretical learning to nursing practice, which is very important to strengthening perceptual abilities, skills, knowledge, and how to behave in nursing practice [14]. In addition, professional identity is the outcome of nursing education institutions and includes decision-making elements for choosing a future career [7], [8], [15]. Nursing careers are known as careers related to busyness, caring for other people, hard work, having job security, but failing in ideal careers in terms of respect, autonomy, financial remuneration, and respect compared to other health professions [16].

Nursing career opportunities can be created by nursing educational institutions by focusing on knowledge and skills and a strong professional identity as a nurse [14]. The development of a professional identity 
starts from the beginning of nursing education, clinical practice, work and continues throughout the career as a nurse [7]. Nurses obtain self-concept and professional identity from education, experience, work values, cultural and social values, work environment, and public image [17]. The impact of a weak nursing professional identity will affect job satisfaction and retention of being a nurse [7], [8], [11], a sense of belonging, selfconfidence, self-esteem, self-image, public recognition, and commitment [13], [18]. Therefore, the importance of the character of a professional identity for nursing has a sense of pride through caring [11].

Professionalism is an Islamic work ethic that is contained in the Al Quran Surah Al Isra Verse 84 as follows: "Say: "Everyone acts according to their respective circumstances". Then your Lord knows better who is more correct in the way. The meaning of this surah is to work in following your field of expertise. Nurses will be considered to be professional if they work in the right position according to their competence. Professional nurses are the expected outcomes of the School of Nursing, Universitas Muhammadiyah Yogyakarta (UMY), where nursing alumni can reflect the character of a professional identity as a nurse. School of Nursing UMY is a nursing education institution that has been accredited A since 2015 and maintains the accreditation in 2019 for both academic and professional programs. The total of nursing alumni was 1,564 graduates from the academic year 2004 to 2019 . Nursing career of alumni includes civil servants, clinical nurses at regional and government hospitals, nurse educators, occupational health nurses, leaders or managers in various health and nursing organizations, and a professional nurses at the international level such as in Saudi Arabia and Japan. The success in developing a professional identity as a continuous transition from education to becoming a professional nurse is influenced by many factors [18]. Therefore, nursing alumni experiences in PID at various nursing careers are necessary to explore.

\section{Methods}

This study was descriptive qualitative with a phenomenological approach [19], [20]. The study participants were seventeen alumni who have a minimum of 2 years of working experience and worked in various nursing careers, such as nurse educators, nurse managers, clinical nurses abroad, and in the country. The participants were recruited through a maximum variation sampling technique. The data were collected through WhatsApp video call within 60-90 min from March to June 2020. Data collection was conducted through a semi-structured interview and began after obtaining consent from nursing alumni. The interview was audio-recorded, transcribed verbatim, and validated by re-listening to the recording and re-reading the transcript by the researchers. Questions on the interview included supporting factors to develop professional identity, the type of challenges they faced, and how they would describe their living experience in a nursing career.

Data analysis was used seven analysis methods by Colaizzi and Nvivo 12 plus software. The Colaizzi steps were as follows: (1) data familiarization; (2) significant statement identification; (3) meanings formulation; (4) themes clusterization; (5) develop of exhaustive description; (6) fundamental structure production; and (7) fundamental structure verification [21], [22]. The analysis was supported by Nvivo $12^{\mathrm{TM}}$ plus three senior qualitative researchers ensured software and oversight; they reviewed narrative syntheses and a sample of interview transcripts and field notes to support the analysis. The four criteria of Carnevale's to ensure the trustworthiness in qualitative nursing studies were used including credibility, conformability, saturation, and transferability [23]. Table 1 shows the strategies to ensure the data in this study. The permission to conduct this study was granted from the Master of Nursing, UMY. The Ethical Committee approved ethical clearance with the number 1102/ KEP-UNISA/II/2020. The participants were informed in writing and orally that participation was voluntary and ensured their confidentiality. The research data could only be access all of the research data.

Table 1: Strategies to ensure the rigor of study

\begin{tabular}{ll}
\hline $\begin{array}{l}\text { Trustworthiness criteria by } \\
\text { Carnevale's (2002) }\end{array}$ & Strategies used in the study \\
\hline Credibility & - Prolonged engagement \\
& - Discussion of findings with experts \\
& - Reflectivity \\
Confirmability & - Member checking \\
Saturation & - An audit trail (complete field notes and interview transcript) \\
Transferability & - Sample size flexible \\
\hline
\end{tabular}

\section{Results}

Majority of participants is female $(58.82 \%$; $n=10)$, and (41.18\%; 7) were male nursing alumni. The majority age of participants ranged from 31 to 35 years old, with nine alumni. The maximum length of working experience was ranging from 6 to 10 years, with 13 alumni. Then, majority level of education is Bachelor Nursing Science with ten alumni. Nine alumni were married in this study. Most of the participants worked as clinical nurses in Indonesia, became occupational health nurses, civil servants in government hospitals, and nurses in a private hospital. Table 2 shows the demographics of the participants. 
Table 2: Participants' demographics

\begin{tabular}{|c|c|c|}
\hline Demographics & Nurse participants (n) & $(\%)$ \\
\hline \multicolumn{3}{|l|}{ Gender } \\
\hline Female & 10 & 58.82 \\
\hline Male & 7 & 41.18 \\
\hline \multicolumn{3}{|l|}{ Age $(y)$} \\
\hline $21-25$ & 2 & 11.76 \\
\hline $26-30$ & 5 & 29.41 \\
\hline $31-35$ & 9 & 52.94 \\
\hline $36-40$ & 1 & 5.89 \\
\hline \multicolumn{3}{|l|}{ Working experience $(\mathrm{y})$} \\
\hline $0-5$ & 3 & 17.65 \\
\hline $6-10$ & 13 & 76.47 \\
\hline $11-15$ & 1 & 5.88 \\
\hline \multicolumn{3}{|l|}{ Education } \\
\hline Bachelor (S.Kep., Ns) & 10 & 58.82 \\
\hline Master of Nursing & 5 & 29.42 \\
\hline Master of Public Health & 1 & 5.88 \\
\hline Ph.D. in Public Health & 1 & 5.88 \\
\hline \multicolumn{3}{|l|}{ Marital Status } \\
\hline Single & 8 & 47.06 \\
\hline Married & 9 & 52.94 \\
\hline \multicolumn{3}{|l|}{ Nursing careers } \\
\hline Practical nurse in abroad & 4 & 23.53 \\
\hline Practical nurse in Indonesia & 5 & 29.41 \\
\hline Nurse educator & 4 & 23.53 \\
\hline Nurse manager & 4 & 23.53 \\
\hline
\end{tabular}

This article discusses factors supporting the development of UMY nursing alumni's professional identity in several nursing careers in Indonesia. Two themes emerged from the data analysis: Internal motivation to enhance nursing career and External support driving nursing career. Table 3 shows themes and sub-themes of the study findings.

Table 3: Themes and sub-themes of the study

\begin{tabular}{ll}
\hline Themes & Sub-themes \\
\hline Internal motivation to enhance nursing career & • having a great personal motivation \\
& • developing expertise \\
External support driving nursing career & • family encouragement \\
& • supports from a leader \\
& • accreditation and credential \\
& • exemplary role model \\
& • positive nursing image \\
\hline
\end{tabular}

\section{Themes 1. Internal motivation to enhance}

\section{nursing career}

Based on the data, it was evident that nursing alumni perceived that personal motivation is essential to develop professional identity while working as a professional nurse. As a result, all participants shared and discussed deeply based on their internal motivation to improve their nursing profession careers. There were two sub-themes identified: having great personal motivation and developing expertise.

\section{Having great personal motivation}

Findings showed that nursing alumni had a strong motivation to improve nursing career through continuing education. Most of the participants stated that they had a high initiative to develop personal and professional development in the nursing profession. The following is an expression from the participants.

"After working for almost 7 years, I reported to the BKD provincial. I said that "Sir, I would like to leave the social services to move to the hospital that can facilitate my career path and further education" I said finally, a few months later I moved to the psychiatric hospital and I was placed in the outpatient clinic. Only a year and a half later, I was immediately appointed as the head of nurse in this room, my motivation to move jobs. It is just for my personal development to improve my career path and continue to study." (P5)

"...from myself which is the motivation to continue learning in Ph.D. education. Internally, my motivation is to upgrade myself and enhance my career. Then, I would spend my funding for my personal development if there was no financial support from my workplace..." (P3).

\section{Developing expertise}

Findings showed that nursing alumni develop their expertise through training and participating in an organization. The participant explained in the following statements.

"...as a surgical nurses, I want to develop my expertise in orthopedics. I usually propose to participate in training, and I get sponsored. So, it is so nice to develop my self..." (P1)

"...to support my career apart from lecturer certification and continue study to Master of Nursing and I took specialist in wound healing. I also continue to take my initiative to find training and improve my expertise in wound healing. Then, I joined in wound nurses organization and became a secretary in my area..."(P17).

\section{Theme 2. External support driving nursing} careers

Based on the data, nursing alumni perceived that nursing career was driven by external supports, including institutional and sociocultural support. There were five sub-themes identified: family encouragement, support from a leader, supportive working environment, exemplary role model, and positive nursing image.

\section{Family encouragement}

The participants stated that parents provided support to develop professionalism in the nursing career. It is the following statements from participants.

"My family members are very supportive to my development. They set me free and entrust everything to me because that's the work demand."(P3)

"I was given many opportunities to take part in workshops and heart training for 3 months. At first, I hate why it was not other people to be asked to come along. However, my mother and father encouraged me to be trusted, and there was no second chance. In the end, I said okay, I would try it to develop my self."(P4) 


\section{Supports from a leader}

The participants said that supports developed professional identity from their leader in the workplace. The following is an expression from the participants.

"...the support from the leader who sees human resources as an asset needs to continue to be upgraded. There is also a continuation with the hospital's financial support and the job demands that require accreditation. Thus, sometimes, you should have to participate"(P3)

"The hospital leader is very supportive of education and training for nurses. Training and seminars are always shared by the nursing committee through the nurses groups WhatsApp. The hospital provides financial support so that nurses are put in the first place. The financial problem has been taken care of by the treasurer. It is excellent in my workplace environment felt nice because all of the nurses have fair opportunities to participate in education and training..." (P15)

\section{Accreditation and credentials}

The participants also conveyed that accreditation and credentials can enhance career development and nurses' identity as a professional. The following is an expression from the participants.

"...Back then, the study proposal was very difficuly if there was no accreditation. However, it is now different. All nurses can continue their studies. My leader is eager to encourage us go to school..."(P5)

"credential causes me to improve my status. I'm still in clinical nurse 1, so I should upgrade to clinical nurse 2. Thus, I need to prepare the requirements..."(P4)

\section{Exemplary role model}

The participants said they had exemplary professional nurses who could be used as role models when caring for the patient and supporting their development. The following is the statements of the participants.

"My role model was good. She has succeeded improving employees' performance in professionalism. Her leadership was democratic and she was transparent. That's why my friend and I appreciate her." (P5)

"...I have a role model that is very protective of the patient. His attitude and behavior always ensure patient safety. I learned how to be a professional nurse from him..." (P4)

\section{Positive nursing image}

The participants explained that positive nursing images had been acknowledged by society not only abroad and in Indonesia. Most participants also stated that professional nurses have a sense of belonging and self-confidence to show that their identity as a professional nurse proudly. The following are the statements from the participants.

"I just worked on taking care of the patient totally, and they remembered me, it does not because I pretended to be good, but they remembered what I ever did. It's a tremendous reward for me; for example, I met patient's families several times who gave me a discount when I bought something. They said, "you are a nurse who took care of my child while in the hospital. I thank you for your help." (P5)

"Japanese people already know that Indonesian nurses are diligently considered more famous than others..." (P14)

"...Nurses must have their specialty, that is what we will sell at our workplaces. The points are not easy to underestimate. Like here, nurses are underestimated, and I answered that I am a different nurse. I have integrity and I have a specialty; skills that do not belong to other nurses. So, I can proudly say that I am a professional nurse in a wound specialist..." (P17)

\section{Discussion}

The study was a phenomenology descriptive aiming to explore nursing alumni's experience on supporting factors of PID. The pattern in this sample indicates of broader phenomena of supports confronted by UMY nursing alumni in Indonesia related to the development of professional identity in various nursing careers. A review paper revealed how nurses develop their professional identity in a nursing career, addressed multidimensional factors such as personal, family, institutional, social [3] professional roles, and practice contexts [24]. These supports are present in Indonesia's nursing career to show their identity as professional nurses. Besides, the National League of Nurses defined professional identity as personal and professional development for nurses [25].

Findings revealed that nursing alumni aspiring to become a professional nurse had a strong personal motivation to develop their personal and professional capabilities. Based on the study, it came to light that internal and external contexts had considerably positive influences on enhancing the nursing alumni's career. The data shows that successful professional nurses revealed that they had the initiative to boost their current positions by their efforts and suitable for their willingness to improve their nursing expertise. They continue to study in Master of Nursing or Ph.D. degrees and attended training programs, even though they should pay with our money.

Personal factor is related to professional development which involves self-motivation, selfconfidence, self-resilience, and professional identity. 
Nursing professionalismis determined bythreeattributes, namely cognitive, attitude, and psychomotor. The most important supporting factors in nursing professionalism are personal demographics, experience, education, environment and attitudes [26]. Personal factors are a significant factor in supporting professionalism based on knowledge and skills, professional ethics, professional commitment, self-respect, respect for others, interest, and responsibilities [27]. The individual also uses personality and personal qualities to enhance success in a nursing career, such as motivation, intellegence, altruism and caring behavior. It is supported by Jackson et al. (2007), which encourages professional nurses to actively participated in career development and strengthened personal resilience to reduce vulnerability in facing the difficulties in the workplace and improve quality in the health setting.

The strategies to increase nurses' personal strength of include building positive professional relationships, maintaining positive thoughts, developing emotional insight, achieving a balance of life and spirituality, and becoming more reflective [28]. Education is a critical stage where knowledge and skills are acquired and empowered nurses as health professionals from ordinary people [7]. Furthermore, personal qualities have a significant correlation with academic and clinical performance, and the ability to finishing the nursing education program within 3 years, such as personality, self-control, resilience, self-confidence, and involvement [29]. Nurses have to set goals in the nursing career path to enhance competency through further education and training. As literature mentioned, professional nurses perceived their professional identity, including self (who I am), role (what I do), and context (where I do it) [24], [30].

Furthermore, participants stated that external support had driven their nursing careers, such as family, leader, credential and accreditation, role model, and nursing image. Factors that contribute to Chinese nurses' PID include family support, family income, parent work, family social status and night shifts. Various family factors support Chinese nurses in carrying out their professional roles and showing their professional identity [3]. As mentioned in the literature, family background influences nurses' professional behavior in Iran, including distinctions in family perspectives, moral differences in the family, knowledge learned from family, and the absence of trust related to the family's honesty [31]. Besides, work-family conflicts have a positively affect on the nurses' intention of turnover to move from hospital [32]. Ohio male nurses needed special support regarding personal identification and choosing appropriate strategies in professional nurses' role. The need for educational preparation and training can enhance the competence of nurses to provide safe practices. This workplace support can facilitate the adaptation process and understand the nursing culture [33].
Qualitative data showed that nursing alumni should improve their careers through accreditation and credentials. Evidence revealed that credentials influence the integration of male nurses' professional identity and have a strong correlation with job satisfaction and organizational commitment [34]. Furthermore, job satisfaction and rewards simultaneously affect nurses' turnover intention in hospitals [32]. Also, application of spirituality in the workplace could shapes positive perception and reduce nurses' turnover in Indonesia [35]. In this study, there is a positive impact on professional identity, which nursing alumni had the internal motivation to join in continuing professional development programs that are linear with their expertise. Moreover, participants stated that they need to show their expertise through nursing services to get public recognition. It indicates that a sense of belonging in the nursing profession had evolved with their identity as a professional nurse. Also, the Indonesian Nursing Act of 2014 stated that nursing services are defined as a form of professional service that is an integral part of the health service based on the nursing science and art that aimed at individuals', families', groups' or communities health [36].

Drawing from the study finding, it has provided with the information that it is not only family and institutional support that encouraged nursing alumni to enhance their professional identity, but also role models and positive nursing image. A role model in the working environment can help new nurses find out their roles and responsibilities as professional nurses. The exemplary role model provides encouragement and support for the development of professional identity [37]. Also, role models have a vital role in forming a professional identity for nursing students to become professional nurses [8]. Besides, the succes in developing professional identity are influenced not only by positive role models but also by peer support in clinical practice [38]. Furthermore, Indonesian nurses have perceived positive self-image by implementing of spiritual nursing services and Islamic cultural values, including prioritizing caregivers suitable with gender. They are also considered to perform many roles in hospitals and various job positions that influence the strong professional identity of nurses in the community [39]. In contrast, the perception of Indonesian nurses' negative image as physician assistants having lower status [40], [41] could be an obstacle for younger generation's motivation to choose nursing as their career [39]. The positive aspect of nurses' professionalism must be understood and incorporated in retaining experienced nurses in the nursing profession and attracting the young generation to choose nursing as a viable career [42].

The finding reveals factors supporting UMY nursing alumni to become professional nurses in several nursing careers in Indonesia. The finding was supported by the social capital theory that found a microlevel, mesolevel, and macrolevel phenomenon [43], and 
supports the occupational career [44]. It facilitates individuals and and organizations' actions within social structures; and the achievement of personal and group goals [43], [44]. It is expected that the finding of the study may help to capture the nurses' identity in professional roles in Indonesia and to provide some recommendations that could address a positive nursing image. Findings may also provide a career pathway for nurses to pursue their career in top position. For authorities, the findings may be used for strengthening nurses' professional identity and positive nursing image as a viable career through nursing regulation and nursing education.

\section{Conclusion}

The descriptive phenomenology study sought to discover the essential factors supporting professional development, especially UMY alumni's identity in Indonesia. The finding obtained from this study could not be generalized to the whole population. This paper describes the findings of supporting factors for developing a professional identity influenced by internal factors (personal motivation) and external factors (institutional and sociocultural). Nursing alumni have worked in various professional roles that contributed to the nursing workforce. The supporting of PID impacts personal and professional capability and strengthens nurses' careers. Some aspects of this study may reflect the initial challenges encountered by Indonesian nursing alumni and may support the nursing career progression. These findings can contribute to the curriculum development in the Bachelor nursing education program, including a hidden curriculum related to professional identity as nurses suitable for nursing institution's culture. There should be a focus on internalization values, characteristics, sense of belonging, and personal identification in becoming professional nurses.

\section{Acknowledgment}

The authors would like to thank nursing alumni who participated in this study.

\section{References}

1. Terry J. In the middle: A qualitative study of talk about mental health nursing roles and work. Int $\mathrm{J}$ Ment Health Nurs. 2020;29(3):414-26. https://doi.org/10.1111/inm.12676

\section{PMid:31799780}

2. Fitzgerald A. Professional Identity: A Concept Analysis. Paper Presented at the Nursing Forum; 2020.

3. Mao A, Lu SE, Lin Y, He M. A scoping review on the influencing factors and development process of professional identity among nursing students and nurses. J Prof Nurs. 2021;37(2):391-8. https://doi.org/10.21203/rs.2.13395/v2

PMid:33867096

4. Nguyen TM, Jones D, Ngo KL, Hayes MJ. Developing professionalism in dentistry: Asystematic review. Med Ed Publish. 2017;6(2):85. https://doi.org/10.15694/mep.2017.000085

5. Passi V, Doug M, Peile E, Thistlethwaite J, Johnson N Developing medical professionalism in future doctors: A systematic review. Int J Med Educ. 2010;1:19-29. https://doi. org/10.5116/ijme.4bda.ca2a

6. Mylrea MF, Sen Gupta T, Glass BD. Developing professional identity in undergraduate pharmacy students: A role for selfdetermination theory. Pharmacy (Basel). 2017;5(2):16. https:// doi.org/10.3390/pharmacy5020016

PMid:28970428

7. Al-Eraky MM, Donkers J, Wajid G, Van Merrienboer JJ. Faculty development for learning and teaching of medical professionalism. Med Teach. 2015;37 Suppl 1:S40-6. https:// doi.org/10.3109/0142159x.2015.1006604

PMid:25803591

8. Browne CWall P, Batt S, Bennett R. Understanding perceptions of nursing professional identity in students entering an Australian undergraduate nursing degree. Nurse Educ Pract. 2018;32:90-6. https://doi.org/10.1016/j.nepr.2018.07.006 PMid:30098517

9. Barbarà-i-Molinero A, Cascón-Pereira R, Hernández-Lara $A B$. Professional identity development in higher education: influencing factors. Int J Educ Manag. 2017;31(2):189-203. https://doi.org/10.1108/ijem-05-2015-0058

10. Pimenta $A D$, Souza $M$. The Professional Identity of Nursing in the Papers. Vol. 26. Reben Texto and Contexto Enfermagem; 2017. https://doi.org/10.1590/0104-07072016004370015

11. Guo YJ, Yang L, Ji HX, Zhao Q. Caring characters and professional identity among graduate nursing students in China a cross sectional study. Nurse Educ Today. 2018;65:150-5. https://doi.org/10.1016/j.nedt.2018.02.039 PMid:29579567

12. Johnson M, Cowin LS, Wilson I, Young H. Professional identity and nursing: Contemporary theoretical developments and future research challenges. Int Nurs Rev. 2012;59(4):562-9. https:// doi.org/10.1111/j.1466-7657.2012.01013.x PMid:23134142

13. Takase $S$, Tsuchiya, R, Nishizawa $Y$. The influence of personal characteristics and learning motivation on the professional identity of nursing students. Hirosaki Med J. 2019;69(1-4):66-77.

14. Fitzgerald AM. The Experience of Professional Identity Development in Graduating Nursing Students; 2016.

15. Noble C, O'Brien M, Coombes I, Shaw PN, Nissen L, Clavarino A. Becoming a pharmacist: Students' perceptions of their curricular experience and professional identity formation. Curr Pharm Teach Learn. 2014;6(3):327-39. https://doi. org/10.1016/j.cptl.2014.02.010

16. Liaw SY, Wu LT, Chow YL, Lim S, Tan KK. Career choice and perceptions of nursing among healthcare students in higher educational institutions. Nurse Educ Today. 2017;52:66-72. https://doi.org/10.1016/j.nedt.2017.02.008 PMid:28267629

17. Ten Hoeve $Y$, Jansen $G$, Roodbol P. The nursing profession: Public image, self-concept and professional identity. A discussion paper. J Adv Nurs. 2014;70(2):295-309. https://doi. 
org/10.1111/jan.12177

PMid:23711235

18. Neishabouri M, Ahmadi F, Kazemnejad A. Iranian nursing students' perspectives on transition to professional identity: A qualitative study. Int Nurs Rev. 2017;64(3):428-36. https://doi. org/10.1111/inr.12334 PMid:27882563

19. Asih ID. Fenomenologi Husserl: Sebuah cara "kembali ke fenomena". J Keperawatan Indonesia. 2005;9(2):75-80. https:// doi.org/10.7454/jki.v9i2.164

20. Streubert H, Carpenter D. Qualitative Research in Nursing: Advancing the Humanistic Perspective. $3^{\text {rd }}$ ed. Philadelphia, PA: JB Lippincott; 2003.

21. Colaizzi PF. Psychological research as the phenomenologist views it. In: Existential-Phenomenological Alternatives for Psychology. New York: Oxford University Press; 1978. p. 48-71.

22. Morrow R, Rodriguez A, King N. Colaizzi's descriptive phenomenological method. Psychologist. 2015;28(8):643-4.

23. Carnevale FA. Authentic qualitative research and the quest for methodological rigour. Can J Nurs Res Arch. 2016;34(2):121-8. PMid: 12425004

24. Rasmussen $\mathrm{P}$, Henderson A, Andrew N, Conroy $T$. Factors influencing registered nurses' perceptions of their professional identity: An integrative literature review. J Contin Educ Nurs. 2018;49(5):225-32. https://doi. org/10.3928/00220124-20180417-08 PMid:29701865

25. Hensel D, Middleton MJ, Engs RC. A cross-sectional study of drinking patterns, prelicensure nursing education, and professional identity formation. Nurse Educ Today. 2014;34(5):719-23. https://doi.org/10.1016/j. nedt.2013.08.018 PMid:24070819

26. Ghadirian F, Salsali M, Cheraghi MA. Nursing professionalism: An evolutionary concept analysis. Iran J Nurs Midwifery Res. 2014;19(1);1-10. https://doi.org/10.1111/2047-3095.12082 PMid:24554953

27. Memarian R, Salsali M, Vanaki Z, Ahmadi F, Hajizadeh E. Professional ethics as an important factor in clinical competency in nursing. Nurs Ethics. 2007;14(2):203-14. https://doi. org/10.1177/0969733007073715 PMid:17425149

28. Jackson D, Firtko A, Edenborough M. Personal resilience as a strategy for surviving and thriving in the face of workplace adversity: A literature review. J Adv Nurs. 2007;60(1):1-9. https://doi.org/10.1111/j.1365-2648.2007.04412.x PMid:17824934

29. Pitt V, Powis D, Levett-Jones $T$, Hunter $S$. The influence of personal qualities on performance and progression in a pre-registration nursing programme. Nurse Educ Today. 2014;34(5):866-71. https://doi.org/10.1016/j.nedt.2013.10.011 PMid:24231636

30. Frechette J, Bitzas V, Kilpatrick K, Aubry M, Lavoie-Tremblay M.
A hermeneutic phenomenological study of paediatric intensive care unit nurses' professional identity following hospital redesign: Lessons learned for managers. J Nurs Manag. 2020;28(4):872-80. https://doi.org/10.1111/jonm.13012 PMid:32219900

31. Alipour F, Shahvari Z, Asghari F, Samadi S, Amini H. Personal factors affecting medical professionalism: A qualitative study in Iran. J Med Ethics History Med 2020;13:3. https://doi. org/10.18502/jmehm.v13i3.2842

32. Adityarini $D$, Andry A, Adhikara MA. Hallo effect in the turnover intention of nurses at hospital "X". JMMR. 2020;9(1):85-99. https://doi.org/10.18196/jmmr.91119

33. Delgado C. Competent and safe practice: A profile of disciplined registered nurses. Nurse Educ 2002;27(4):159-61. https://doi. org/10.1097/00006223-200207000-00005 PMid: 12131809

34. Wallen AS, Mor S, Devine BA. It's about respect: Gender professional identity integration affects male nurses' job attitudes. Psychol Men Masc. 2014;15(3):305. https://doi. org/10.1037/a0033714

35. Fitriasari N. Spirituality in the workplace: Solution to reduce nurse turnover intention. JMMR. 2020;9(2):146-53. https://doi. org/10.18196/jmmr.92125

36. LRI. Law of the Republic of Indonesia No. 34 Year 2014 on Nursing Act: President of the Republic of Indonesia; 2014.

37. Baldwin A, Mills J, Birks M, Budden L. Reconciling professional identity: A grounded theory of nurse academics' role modelling for undergraduate students. Nurse Educ Today 2017;59:1-5. https://doi.org/10.1016/j.nedt.2017.08.010

PMid:28898727

38. Attenborough J, Abbott $\mathrm{S}$. The impact of nursing and midwifery council revalidation on the professional identity of academic staff in a higher education institution: A qualitative study. Nurs Open. 2019;6(2):434-42. https://doi.org/10.1002/nop2.224 PMid:30918694

39. Gunawan J, Aungsuroch Y, Sukarna A, Efendi F. The image of nursing as perceived by nurses: A phenomenological study. Nurs Midwifery Stud. 2018;7(4):180-5. https://doi.org/10.4103/ nms.nms_24_18

40. Shields L, Hartati LE. Nursing and health care in Indonesia. J Adv Nurs. 2003;44(2):209-16.

PMid: 14521687

41. Sommers CL, Tarihoran DE, Sembel S, Tzeng HM. Perceived images and expected roles of Indonesian nurses. Nurs Open. 2018;5(4):501-6. https://doi.org/10.1002/nop2.156 PMid:30338095

42. Wynd CA. Current factors contributing to professionalism in nursing. J Prof Nurs. 2003;19(5):251-61.

43. Ritchie LA, Gill DA. Social capital theory as an integrating theoretical framework in technological disaster research. Soc Spect. 2007;27(1):103-29. https://doi. org/10.1080/02732170601001037

44. Dubos R. Social Capital: Theory and Research. Milton Park, Abingdon-on-Thames: Routledge; 2017. 